\title{
Understanding ASEAN
}


Macmillan International College Editions will bring to university, college school and professional students, authoritative paperback books covering the history and cultures of the developing world, and the special aspects of its scientific, medical, technical, social and economic development. The International College programme contains many distinguished series in a wide range of disciplines, some titles being regionally biassed, others being more international. Library editions will usually be published simultaneously with the paperback editions. For full details of this list, please contact the publishers.

Titles of Related Interest:

J Wong: ASEAN Economies in Perspective Justus M van der Kroef: Communism in South-east Asia S Y Lee and J C Jao: Financial Structures and Monetary Policies in Southeast Asia 


\title{
Understanding ASEAN
}

\author{
edited by \\ Alison Broinowski
}

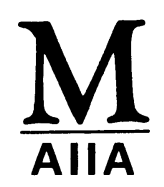


(C) Alison Broinowski: 1982; Chapter 1 (C) Wang Gungwu: 1982; Chapter 2 (C) Roger Irvine: 1982; Chapter 3 @ David Irvine: 1982; Chapter 4 @ Amado Castro: 1982; Chapter 5 @ Michael Richardson: 1982; Chapter 6 C Allan Gyngell: 1982; Chapter 7 (C) Frank Frost: 1982; Chapter 8 @ Alan Rix: 1982; Chapter 9

(c) Ho Kwon Ping: 1982; Chapter 10 (c) Robyn Lim: 1982.

First edition 1982

Southeast Asian Reprint 1983

Published by

THE MACMILLAN PRESS LTD

London and Basingstoke

Companies and representatives throughout the world

in association with

The Australian Institute of International Affairs

Typeset by Illustrated Arts in 11/12 IBM Press Roman

ISBN 978-1-349-81252-3 ISBN 978-1-349-81250-9 (eBook)

DOI 10.1007/978-1-349-81250-9

The paperback edition of this book is sold subject to the condition that it shall not, by way of trade or otherwise, be lent, resold, hired out, or otherwise circulated without the publisher's prior consent in any form of binding other than that in which it is published and without a similar condition including this condition being imposed on the subsequent publisher.

Having as its object the scientific study of international questions, the Australian Institute of International Affairs, as such, does not express opinions or advocate policies. The views expressed in this book are therefore the authors' own. 


\section{Contents}

Map of Southeast Asia Showing ASEAN Countries viii

Editor's Foreword $\quad$ ix

Notes on the Contributors xii

Abbreviations $\quad$ xiv

1. Introduction: ASEAN between Tradition and Modernity

Wang Gungwu $\quad 1$

2. The Formative Years of ASEAN: 1967-1975 Roger Irvine 8

3. Making Haste Less Slowly: ASEAN from 1975 David Irvine

4. ASEAN Economic

Co-operation Amado Castro

70

5. ASEAN and Indo-Chinese Refugees

Michael Richardson 92

6. Looking Outwards: ASEAN's External Relations

Allan Gyngell $\quad 115$

7. ASEAN and Australia Frank Frost 144 
8. ASEAN and Japan:

More than Economics

Alan Rix

9. ASEAN: The Five Countries

10. Conclusion: East-West and North-South

Statistical Tables

Notes and References

A. The ASEAN Declaration (Bangkok Declaration, 1967)

B. Treaty of Amity and Co-operation in Southeast Asia (1976)

C. Declaration of ASEAN Concord (1976)

278

D. The Agreement of ASEAN Preferential Trading Arrangements (1977)

E. Kuala Lumpur Declaration (ZOPFAN Declaration, 1971)

F. Joint Press Communiqué of ASEAN Heads of Governments (Bali, 1976)

Further Reading

Index 


\section{List of Figures and Tables}

\section{FIGURES}

3.1 ASEAN Organisational Structure Prior to the Bali Summit

3.2 ASEAN Organisational Structure Since 1977

4.1 Structure of ASEAN-CCI

TABLES

4.1 ASEAN: Area and Population 1978

4.2 ASEAN: Gross National Product and Food Production 1978

4.3 ASEAN: Gross Domestic Product 1978

4.4 ASEAN Exports and Imports by General Commodities 1978/79

4.5 ASEAN Countries' Trade by Country 1979

7.1 Australia-ASEAN Trade-Summary

7.2 Australia-ASEAN Trade, by Country 


\section{Map of Southeast Asia Showing ASEAN Countries}

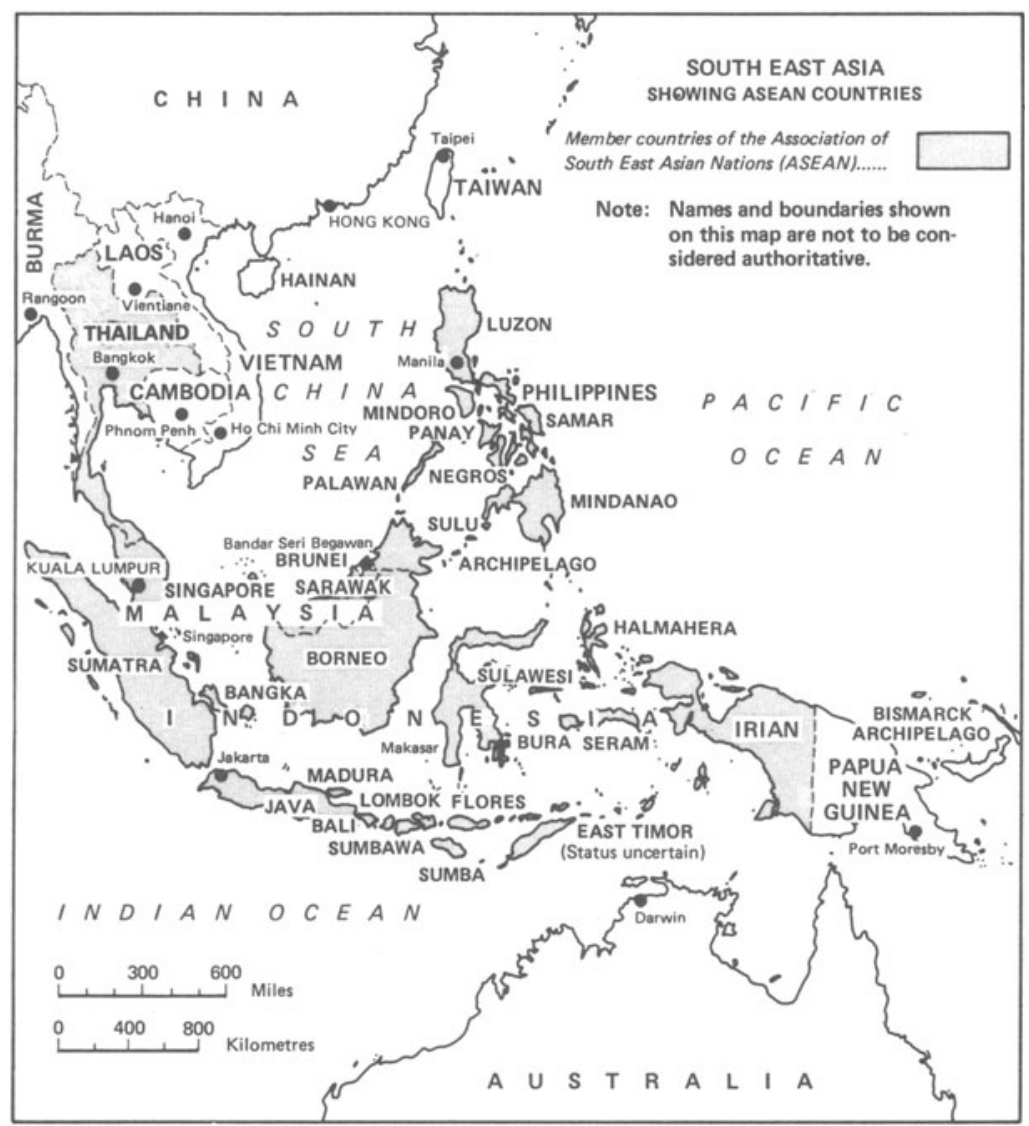




\section{Editor's Foreword}

From ASEAN's earliest days, it has had its share of admirers and detractors. The Association has aroused suspicion, antagonism, resentment, respect and fulsome praise, but most generally, curiosity. Observers of Southeast Asian affairs in government, universities, in business and in the Press continue to question the nature and purpose of ASEAN: why it was formed, what ASEAN gives its members which they would not otherwise have, what effects it has on its neighbours and how they should deal with it, what direction ASEAN will take in the future, and even whether it has a future.

More particular questions also arise: will ASEAN achieve a Zone of Peace? To what extent does regional co-operation override national competition in ASEAN? How will the ASEAN countries reconcile export-led growth with the need to expand their industrial and agricultural production for domestic consumption? Is ASEAN set to follow the newly industrialising countries of East Asia, and to emulate Singapore, ASEAN's most atypical member? What happens to ASEAN when the present leaders change? Will ASEAN become a common market? How will ASEAN cope with Vietnam, the Soviet Union, China, the United States, and with Japan? Will ASEAN develop a common foreign policy?

For people dealing with these questions, the need for a convenient source of information on ASEAN, on both general and specialised levels, has become obvious. This book is an attempt to meet that need by addressing the questions 
in a factual, objective way. It does not aim to arouse controversy or to make sensational revelations: we leave that to others.

In planning the book, I have deliberately crossed disciplines and national boundaries to bring together contributors who are officials, academics and journalists, with a common interest in Southeast Asian affairs: some are nationals of ASEAN countries, while all the others live or have lived in the region. All write here in a private capacity, and from publicly available sources. Since the organisations with which we are professionally associated have not intervened in any way in our project, we do not intend that they should be implicated in any of the views we put forward.

We sought to adopt a consensus approach, discussing the issues among ourselves, reading and commenting on each others' drafts, and trying to arrive at views which could be reflected in the final chapter. Inevitably, differences exist between us on some points, and I have preferred to let these remain to stimulate further inquiry, rather than take them out of the text to achieve unanimity.

Earlier accounts of ASEAN have been written by economists, by foreign relations specialists, by investment consultants and by governments: we are indebted to their detailed work. Others have approached ASEAN from fixed ideological positions which we have tried to avoid. In keeping with the widening impact of ASEAN, and growing interest in it, our intention has been to match that range in our coverage of ASEAN affairs. We have paid close attention to the original blueprint for ASEAN economic co-operation drawn up by a United Nations team in the early 1970s, because it remains relevant as a basis for many of the decisions ASEAN is now making, and because most other studies have neglected it.

As well as tracing the antecedents, development and structure of ASEAN and its co-operative efforts both economic and political, internal and external, we have tried throughout to take account of the Association in terms of its five countries and to give due weight to the differences between them. Chapter 9, which deals in detail with the difficulties facing some of the individual countries, provides a perspective on ASEAN which contrasts with the measured 
optimism of the rest of the book. It is a view supported by some reports of the Asian Development Bank, IBRD and ILO, and its inclusion in any realistic assessment of ASEAN is essential. We have selected ASEAN's relations with Japan and with Australia for special scrutiny, since they demonstrate similarities and differences in ASEAN's approaches to the dialogue countries, as well as in the responses to ASEAN of the two countries themselves. If this way of dealing with the subject succeeds in covering the full range of ASEAN's affairs without sacrificing depth, and if it answers some questions while stimulating others, it will have served its purpose.

I acknowledge with appreciation the support of the Australian Institute of International Affairs, and particularly of its Director, Mr R. L. Harry. Dr Carlyle A. Thayer, Dr Ross Garnaut, Dr Nancy Viviani, Dr John Funston and Dr Peter King read parts of the manuscript and made useful suggestions, and Professor J. A. C. Mackie and Dr Milton Osborne gave me valuable advice in the preparatory stages. Professor Estrella Solidum's work on ASEAN and defence, while it does not appear as a chapter, provided an important point of reference, and will I hope find its proper place in a larger study. I was particularly fortunate, just before completion of the manuscript, in having the opportunity to discuss it with the Secretary-General of ASEAN, Ambassador Narciso G. Reyes, who was present at ASEAN's birth and whose knowledge of ASEAN from the inside has few rivals. Finally, David Irvine's contributions to the book included many hours of hard work beyond those he gave to his own chapter, and I am grateful for them.

ALISON BROINOWSKI Canberra, December 1980 


\section{Notes on the Contributors}

ALISON BROINOWSKI is an officer of the Australian Department of Foreign Affairs, who has also worked as a novelist and journalist. She served in Manila from 1975 to 1978.

Dr AMADO CASTRO was Director of the Economic Bureau of the ASEAN Central Secretariat in Jakarta from 1977 to 1980. $\mathrm{He}$ is Professor of Economics, University of the Philippines.

Dr FRANK FROST is a foreign affairs specialist in the Legislative Research Service of the Parliamentary Library in Canberra. He received his $\mathrm{PhD}$ from the University of Sydney in 1976 for a thesis on 'The Operations of the Australian Army in South Vietnam, 1966-1971: Political and Military Problems'. He has written and published extensively on Southeast Asian affairs.

ALLAN GYNGELL is an Australian foreign service officer who has served in Rangoon and Singapore. From 1978 to 1980 he was a national assessments officer for the ASEAN countries in the Office of National Assessments, Canberra. $\mathrm{He}$ is at present on the staff of the Australian Embassy in Washington.

HO KWON PING is economics editor on the staff of the Far Eastern Economic Review, Hong Kong. He has written, lectured and broadcast extensively on ASEAN affairs.

DAVID IRVINE is an officer of the Australian Department of Foreign Affairs and served in Jakarta from 1976 to 1979. 
ROGER IRVINE was until 1981 an analyst in the Joint Intelligence Organization, Department of Defence, Canberra, concurrently undertaking postgraduate research on ASEAN in the International Relations Department of the Australian National University. He is at present on the staff of the Australian Embassy in Washington.

Dr ROBYN LIM is a Lecturer in the Department of General Studies, University of New South Wales. She holds a PhD in International Relations from the Australian National University and has published mainly on Philippine domestic and foreign policy. Her most recent publication is 'Australia and ASEAN', in Southeast Asian Affairs (ISEAS, Singapore, 1980). She is at present a visiting lecturer in Australian Studies at Tokyo University.

MICHAEL RICHARDSON has worked for the past ten years as the Southeast Asia correspondent of the Melbourne Age, based in Singapore. He was a major contributor to The Boat People (Penguin Books, 1980).

Dr ALAN RIX received his degree from the Australian National University in political science, specialising in Japanese foreign aid. He worked there for two years on the Australia-Japan Economic Research Project, and is at present on a twoyear assignment to the Japan Secretariat, Canberra. He is the author of Japan's Economic Aid: Policy Making and Politics (Croom Helm, 1980).

Professor WANG GUNGWU was Director of the Research School of Pacific Studies, Australian National University, 1975-80. He has been Professor of Far Eastern History at ANU since 1968, having previously been Professor of History in the University of Malaya. He is President of the Australian Humanities Academy (since 1980), and from 1978 to 1980 was President of the Asian Studies Association of Australia. He has written and broadcast extensively on Southeast Asian affairs. His latest book is Community and Nation: Essays on Southeast Asia and the Chinese (Heinemann, 1981). 


\section{Abbreviations}

AAECP

ADB

ASA

ASEAN

ASEAN-CCI

ASPAC

COMECON

CPP

CPT

EC

ECAFE

EEC

ESCAP

IBRD

ICAP

ILO

IMF

MNLF

NPA

SCCAN
ASEAN-Australian Economic Cooperation Programme

Asian Development Bank

Association of Southeast Asia

Association of Southeast Asian Nations

ASEAN Chambers of Commerce and

Industry

Asian and Pacific Council

Council for Mutual Economic Aid

Communist Party of the Philippines

Communist Party of Thailand

European Community (ies)

(United Nations) Economic Commission

for Asia and the Far East

European Economic Community

Economic and Social Commission for

Asia and the Pacific

International Bank for Reconstruction

and Development (World Bank)

International Civil Aviation Policy

(Australian)

International Labour Organisation

International Monetary Fund

Moro National Liberation Front

New People's Army (Philippine)

Special Co-ordinating Committee of ASEAN Nations 
SEAMEO Southeast Asian Ministers of Education Organisation

SEATO Southeast Asia Treaty Organisation

UNCTAD United Nations Conference on Trade and Development

UNDP

UNESCO

United Nations Development Programme

United Nations Educational Scientific and Cultural Organisation

ZOPFAN

Zone of Peace, Freedom and Neutrality ZOPIGN

Zone of Peace, Independence and Genuine Neutrality 